\begin{tabular}{|c|c|c|c|c|c|c|}
\hline \multirow{4}{*}{ Impact Factor: } & ISRA (India) & $=3.117$ & SIS (USA) & $=0.912$ & ICV (Poland) & $=6.630$ \\
\hline & ISI (Dubai, UAE & $=0.829$ & РИНЦ (Russia & $=\mathbf{0 . 1 5 6}$ & PIF (India) & $=1.940$ \\
\hline & GIF (Australia) & $=0.564$ & ESJI (KZ) & $=8.716$ & IBI (India) & $=4.260$ \\
\hline & JIF & $=1.500$ & SJIF (Morocco & $=\mathbf{5 . 6 6 7}$ & OAJI (USA) & $=0.350$ \\
\hline
\end{tabular}

\section{SOI: 1.1/TAS DOI: 10.15863/TAS International Scientific Journal Theoretical \& Applied Science}

p-ISSN: 2308-4944 (print) e-ISSN: 2409-0085 (online)

Year: 2019 Issue: $04 \quad$ Volume: 72

Published: $30.04 .2019 \quad$ http://T-Science.org
QR - Issue

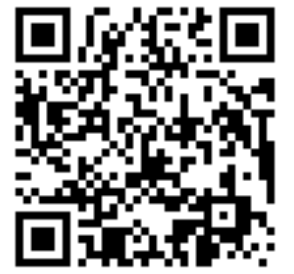

QR - Article

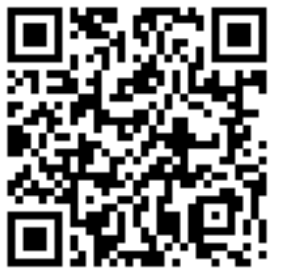

Feruza Shukurovna Djurayeva teacher,

Tashkent State Technical University named after Islam Karimov

UDC 81-13

\title{
COMMUNICATIVE METHOD AGAINST THE TRADITIONAL METHOD OF TEACHING FOREIGN LANGUAGE
}

Abstract: This article highlights in the ranking of popularity among other methods of the English language the first line actively holds the method of teaching which, there are many different approaches to learning English and one of them is a communicative approach.

Key words: methodology, traditional method, non-traditional method, communicative method, teaching, foreign language.

Language: English

Citation: Djurayeva, F. S. (2019). Communicative method against the traditional method of teaching foreign language. ISJ Theoretical \& Applied Science, 04 (72), 517-520.

Soi: http://s-o-i.org/1.1/TAS-04-72-67 Doi: crossef https://dx.doi.org/10.15863/TAS.2019.04.72.67

\section{Introduction}

The teaching of foreign languages, as an integral part of the General education system, is subject to the main trends in the development of this system. This is most clearly expressed in teaching methods.

Today there are two approaches to the study of foreign languages: traditional and non-traditional.

\section{Materials and Methods}

The traditional method of learning English is also called grammar-translation. It consists in the systematic study of grammatical material, phonetics (pronunciation), forms the skills of translation and reading. Students make phrases and sentences from words, using their grammatical knowledge. They make up dialogues, memorize them, learn words on topics, retell texts, perform written grammar exercises[1]. The main features of this approach are: memorization of the material and thoroughness. The peculiarity of the traditional method is that in the process of work, students must master all types of speech activity in a given volume. Naturally, this involves a thorough study of all aspects of the language: grammar, phonetics, vocabulary. There are two main approaches in the traditional method: isolated and complex[2]. An isolated approach is when the teacher teaches first phonetics, then reading, then grammar. With this approach, all aspects of the language are studied separately and in one or another sequence. It is assumed that then it will be possible to "assemble" a real live foreign language into a single system as a model of a children's designer. This is the most reliable way to never learn a language. This is usually taught where no one is seriously interested in learning a language and therefore language learning is only a formality[3].

An integrated approach is when all aspects of the language are studied in conjunction. For example, texts for reading and listening, monologues, dialogues, grammar exercises contain specially selected vocabulary (words) and grammar according to the tasks. Students practice them in all types of speech activity, combine them with each other. The work is organized in such a way that the same words, grammatical phenomena, are repeatedly found in the text and in exercises, are played in situations. Due to this, there is the most effective assimilation of language material. In General, the skill of the teacher working on the traditional method is determined by the ability to "link" all aspects and components in a single effective complex.

The traditional method involves systematic training for quite a long time. Currently, the so-called "communicative" method of language learning is widely used, designed for people who already have at least an elementary level of knowledge. This technique was developed by the British after world war II and appeared in the mid-60s of the last century. Since then, it has changed greatly and gained mass distribution throughout the world. The so-called nontraditional methods of learning foreign languages began to Mature in our country in the Soviet era, but 


\begin{tabular}{|c|c|c|c|c|c|c|}
\hline \multirow{4}{*}{ Impact Factor: } & ISRA (India) & $=3.117$ & SIS (USA) & $=0.912$ & ICV (Poland) & $=6.630$ \\
\hline & ISI (Dubai, UAE & $=0.829$ & РИНЦ (Russia & $=0.156$ & PIF (India) & $=1.940$ \\
\hline & GIF (Australia) & $=0.564$ & ESJI (KZ) & $=8.716$ & IBI (India) & $=4.260$ \\
\hline & JIF & $=1.500$ & SJIF (Morocco & $=5.667$ & OAJI (USA) & $=0.350$ \\
\hline
\end{tabular}

they did not reach the masses, because the grammartranslation method prevailed, and all state educational institutions worked only on it. Much has been said and written about its effectiveness. In the United States, linguist and anthropologist Dell Hymes developed the concept of communicative competence. This was done in response to the concept of linguistic competence of an ideal native speaker developed by Chomsky. Communicative competence clarified what it means to "know the language". In addition to perfect command of the structures of the language, communicative competence also implies the ability to adequately use these structural elements in different situations of communication. This idea was skillfully formulated in the statement of Hymes that "there are rules of use, without which the rules of grammar are useless. All results are achieved by minimizing the use of the student's native language during the lessons[4].

When using this approach, it is very important to teach a person to think in a foreign language, so that he perceives a foreign language without any associations with the native language. With this method of training, the study of theoretical aspects is minimized or absent, and the main attention is paid to live communication, i.e. speaking. When using a communicative approach, it is very important to try to make the lessons as interesting and exciting as possible for the student, as this contributes greatly to the good consolidation of the material and allows the information to remain in the memory of the student for a long time. Topics for discussion are chosen in such a way that they correspond to the range of personal or professional interests of the student and match his age. Often there is a misconception that when using a communicative approach to the study of grammar is given unforgivably little time[5].

In fact, in the process of learning a lot of attention and a sufficient amount of time is paid to vocabulary and grammar, but their development is not the main purpose of learning a foreign language. Now that the first wave of enthusiasm has passed, some aspects of communicative learning are considered more critically. With the introduction of a communicative approach to the teaching of a foreign language there is a problem of teacher training, development of educational materials, testing and evaluation of achievements.

Among the most frequently discussed issues:

1) can communicative training be applied at all stages of training;

2) is it equally suitable for teaching English as a second language and as a foreign language;

3 ) whether it requires the complete rejection of the grammatical curriculum or only to revise it and adapt;

4) how this approach can be assessed; how suitable it is for non-native speakers. Speaking about the educational materials used in the communicative teaching of a foreign language, it should be noted their almost unlimited diversity. Proponents of the communicative campaign consider educational materials as a way to influence the quality of educational communication and language use. Educational materials thus play a primary role in stimulating the communicative use of language. Traditionally, there are three main types of educational materials: text-based, based on the communicative task, realities.

Communicative method of teaching English is more focused on practical needs: grammar - in a very limited form as needed, vocabulary - as needed for practical tasks, practice - in the form of dialogues and life situations. Discussion of real life situations attracts students, arouses keen interest and desire to share their ideas. The teacher directs students to perform a language task. The main place in the communicative teaching of a foreign language is occupied by game situations, work with a partner, tasks to find mistakes that not only allow you to increase the vocabulary, but also teach you to think analytically. Communicative method, first of all, is needed in order to remove the fear of live communication. A person who has no fears that he will not be understood can easily find a common language in a foreign country, owning a standard set of grammatical structures and having a vocabulary of up to 1000 words[6].

But there is a downside to any medal. In this case, it is a poor lexicon and clichéd phrases. And if you add to this grammatical errors, you can easily earn the reputation of not too smart interlocutor.

Many proponents of the communicative approach support the use of authentic materials in the classroom. These can be different language realities such as signs, magazines, advertisements and Newspapers or visual sources around which communication can be built (maps, pictures, symbols, graphs, tables, etc.). Representatives of the "traditional" school believe that non-traditional methods are only suitable to learn the language at the time, for example, for a tourist trip. But to read the language of the newspaper or use it for work, you must first learn the grammar "base". Since the distinctive features of the traditional method - is the extensiveness and thoroughness, in contrast to the intensive methods, students do not try to "dive" and start thinking in the target language, and with a cold grammatical calculation translates each phrase from Russian to English and Vice versa[7].

Traditional methods are used by those who need language not as a means, but as a goal. That is, philologists-linguists, doomed to delve into the structures of the language, and those who want to master it perfectly - to write, read, translate, communicate freely on it. There is no method that can guarantee knowledge forever. But after the end of the course, where teaching was conducted on nontraditional methods, forgetting often happens even 


\begin{tabular}{|c|c|c|c|c|c|c|}
\hline \multirow{4}{*}{ Impact Factor: } & ISRA (India) & $=3.117$ & SIS (USA) & $=0.912$ & ICV (Poland) & $=6.630$ \\
\hline & ISI (Dubai, UAE & $=0.829$ & РИНЦ (Russia) & $=0.156$ & PIF (India) & $=1.940$ \\
\hline & GIF (Australia) & $=0.564$ & ESJI (KZ) & $=8.716$ & IBI (India) & $=4.260$ \\
\hline & JIF & $=1.500$ & SJIF (Morocco & $=5.667$ & OAJI (USA) & $=0.350$ \\
\hline
\end{tabular}

faster. This is due to the fact that such lessons are mainly conversational. The most important problem of non-traditional methods is how not to lose intensively acquired practical skills, not being able to regularly apply them in real life. The most important problem of the traditional method is how to make the acquired extensive knowledge to bring to the level of practical skills. Both problems require, ultimately, the solution of the same problem - to find opportunities for regular practical application of the acquired knowledge.

Let us now consider the communicative method of teaching English. The overview of the methodology given in this section is based on the common European concept of teaching foreign languages in accordance with this methodology, and therefore most of the recommendations are given regarding "foreign languages"[8]. However, it should be noted that the communicative method was originally developed in relation to the English language as the most common means of international communication (which, incidentally, can be seen from the extensive terminology given in this section), but because all that is said below, primarily refers to the teaching of English and tested in practice it is in the course of teaching.

In the English version of both levels, researchers Dj.van Ek and John. Trim is identified as the main components such as:

1) categorized the situation of communication (contacts with the persons in situation of social communication and social interaction, a situation of textual activities, the situation of communication in the socio-cultural context of the target language -speech and social etiquette, etc., a situation associated with mastering the language of educational activities, a situation of acquaintance with the culture of the people and the country of studied language; the communicative situation with native speakers of the target language, suggesting a learning out in the process of interaction with them, assistance, bug fixes, tooltip and etc.);

2) the functions of language and the most appropriate options for their implementation (search and receipt of information, expression and clarification of the relationship, the expression of doubt, pleasure, happiness, fear, etc.);

3) means of designation and transmission of General meanings (existence, space, time, quantity, quality, thinking, relationship, indication);

4) means of transmission of separate (specific) meanings in thematic groups (identity, home and home, environment, daily life, free time and entertainment, travel, relationships with other people, health and care, education, shopping, food, service, attractions and places of visit, language, weather);

5) samples of speech interaction (they relate to the most common and used, as a rule, fixed types of interaction, for example, in the process of making purchases and orders, search and obtain information, meetings with people, walking around the city, learning and naming time, discussion, etc.);

6) the types of texts, auditory, printed and written materials that can be or become sources of information, and their respective perception skills;

7) list of materials, the knowledge of which involves the mastery of language in socio-cultural context (cross-cultural realities, the received samples of communication, national traditions, rituals, habits, forms of expression of politeness, gestures, etc.);

8) the list of skills that the student must possess in order to compensate for the shortcomings in the knowledge of a foreign language (in the process of reading and auditory perception of foreign language speech, speaking and writing, in the process of interaction with a native speaker or a more experienced interlocutor in the language);

9) the list of skills required to study a foreign language in all types of speech activities, in working with various sources, in independent work and selfassessment[9].

\section{Conclusion}

As with any method of learning a foreign language, the communicative method has its drawbacks. The main drawback is that it is quite difficult for a beginner to learn a foreign language to delve into the difficult grammatical basics, presented immediately in a foreign language. In addition, the following disadvantages can be identified:

Complete abandonment of the native language, which is mandatory in communicative teaching methods, can cause stress in untrained students.

Mandatory work in pairs and in a group excludes the opportunity to work with the teacher one-on-one.

The teacher using the communicative method of teaching, during the lesson can not pay enough attention and time to each pairlgroup.

Knowledge of a foreign language involves different types of speech activities: speaking, understanding foreign language speech by ear (listening), writing, reading and reading comprehension. Each of these types involves its own methods of working on them. Accordingly, the method used for teaching, for example, speaking, is hardly suitable for teaching writing.

Therefore, from the point of view of different tasks, any method has its weaknesses and strengths. Each of these techniques has its positive and negative sides. But when used correctly, they effectively help in language learning. Today, without knowledge of foreign languages it is difficult to find a promising high-paying job, knowledge of languages is your chance, a chance for a decent life. A communicative method opens up huge opportunities that will provide us and our children a bright future. 


\begin{tabular}{|c|c|c|c|c|c|c|}
\hline \multirow{4}{*}{ Impact Factor: } & ISRA (India) & $=3.117$ & SIS (USA) & $=0.912$ & ICV (Poland) & $=6.630$ \\
\hline & ISI (Dubai, UAE & $=0.829$ & РИНЦ (Russia & $=\mathbf{0 . 1 5 6}$ & PIF (India) & $=1.940$ \\
\hline & GIF (Australia) & $=0.564$ & ESJI (KZ) & $=8.716$ & IBI (India) & $=4.260$ \\
\hline & JIF & $=1.500$ & SJIF (Morocco & $=5.667$ & OAJI (USA) & $=0.350$ \\
\hline
\end{tabular}

\section{References:}

1. (1981). The choice of teaching methods in the secondary school. Edited by Y. K. Babanskiy (Eds.). Moscow: Pedagogy.

2. Kolker, Y. M. (2000). Practical methods of teaching a foreign language. Moscow.

3. (1985). The communicativeness of teaching in the practice schools, under the editorship of E. I. Passov (Eds.). Moscow: Ed. Education.

4. Passov, E. I. (1985). Communicative method of teaching foreign language speaking. (p.208). Moscow.

5. Passov, E. I. (1991). Communicative method of teaching foreign language speaking. (p.223). Moscow: Education.

6. Rakhmanina, M. B. (1998). Typology of methods of teaching foreign languages. Moscow.
7. Lucantoni, P. (2002). Teaching and assessing skills in English as a second language. (p.82). Cambridge: Cambridge University Press.

8. McDonough, J., \& Shaw, C. (2003). Materials and Methods in ELT: A teacher's guide. 2nd edition. (p.280). Malden: Blackwell.

9. Richards, J. C., \& Rodgers, T. S. (2001). Approaches and Methods in Language Teaching. (p.171). Cambridge: Cambridge University Press.

10. Savignon, S. J. (2000). Communicative language teaching. In Byram, Michael (Eds.). Routledge Encyclopedia of Language Teaching and Learning. [Книга]. (pp.125-129). London: Routledge.

11. Thacker, C., \& Pelteret, C. (2007). English in Mind. Teacher's Book 1. (p.130) Cambridge: Cambridge University Press. 